\title{
Analysis of Air Pollutants in Xiong'an New Area Based on MATLAB Grey Model
}

\author{
Ying Xie*, Wenjun Wang, Baochang Li, Zhiwei Zhao, Lei He \\ Baoding University, Baoding, China \\ Email: *xy2012@sina.com
}

How to cite this paper: Xie, Y., Wang, W.J., Li, B.C., Zhao, Z.W. and He, L. (2018) Analysis of Air Pollutants in Xiong'an New Area Based on MATLAB Grey Model. Open Journal of Air Pollution, 7, 298-308. https://doi.org/10.4236/ojap.2018.74015

Received: October 17, 2018

Accepted: December 22, 2018

Published: December 25, 2018

Copyright $\odot 2018$ by authors and Scientific Research Publishing Inc. This work is licensed under the Creative Commons Attribution International License (CC BY 4.0).

http://creativecommons.org/licenses/by/4.0/ (c) (i) Open Access

\begin{abstract}
The purpose of this paper is to study the air pollutants in Xiong'an New Area based on MATLAB grey model [1]. From 2011 to 2016, the results of sulfur dioxide $\left(\mathrm{SO}_{2}\right)$, nitrogen dioxide $\left(\mathrm{NO}_{2}\right)$ and inhalable particulate matter $\left(\mathrm{PM}_{1 \mathrm{O}}\right)$ detected at monitoring points in the three counties of Xiong'an were analyzed. According to the national environmental air quality standard [2], the air quality in Xiong'an New Area was reasonably evaluated based on grey model in MATLAB. Judging from the weight of pollution factors in the model, sulfur dioxide $\left(\mathrm{SO}_{2}\right)$ is the controlling factor of air quality in Xiong'an New Area, and the weight of nitrogen dioxide $\left(\mathrm{NO}_{2}\right)$ gradually increases. The main sources of the three pollutants were obtained by comprehensive data analysis, and a grey model was established according to the mass concentration of the main air pollutants, and the grey forecasting model was tested. The experimental results show that the model can be effectively applied to the forecasting of ambient air quality. On this basis, the present situation of atmospheric environmental quality in Xiong'an New Area and suggestions for improvement are obtained.
\end{abstract}

\section{Keywords}

Xiong'an New Area, Air Pollution, Grey Model, Forecasting, Suggestion

\section{Introduction}

On April 1, 2017, the Central Committee of the Communist Party of China (CPC) and the State Council announced their decision to establish Xiong'an New Area in Hebei Province. Xiong'an New Area is located in the hinterland of Beijing, Tianjin and Hebei, with obvious geographical advantages. It is another New Area of national significance after Shenzhen Special Economic Zone and Pudong New Area in Shanghai. The key task of planning and building Xiong'an New Area is to relax the non-capital functions of Beijing, build a green and intel- 
ligent new city and create a beautiful ecological environment. Like other regions in Beijing, Tianjin and Hebei, the three counties in Xiong'an New Area have long been plagued by environmental pollution, especially atmospheric pollutants [3] [4] [5] [6].

The pollutants in the atmosphere are mainly composed of chemical pollutants and particulates, etc. In order to protect and improve the living environment of human beings, many domestic scholars have investigated the air pollution in cities. The main pollutants in the atmosphere are atmospheric particulates, sulfur dioxide and nitrogen oxides [7] [8] [9] [10] [11]. According to the situation of urban air pollution, many experts consider and evaluate it from these three aspects. At present, grey system theory has become an important forecasting method, including decision-making, evaluation, planning and control, system analysis and modeling. (Grey system theory is based on the concept of associative space, smooth discrete function and other concepts to define gray derivatives and gray differential equations, and then use discrete data columns to build dynamic models in the form of differential equations, since this is the basic model of the intrinsic gray system, and the model is approximate Non-unique, so this model is a gray model, which is denoted as GM (Grey Model), that is, the gray model is generated by using discrete random numbers to become random, which is significantly weakened and more regular. A model of the equation form facilitates the study and description of its changing process.) In particular, it has a unique analysis and model building method, short time series of statistical data and incomplete information systems [12] [13] [14]. Many researchers in China have established a grey system, and many doctors and researchers have applied the grey system to research [15] [16] [17] [18] [19].

There are few applications of the grey theoretical model in atmospheric environment prediction. Using the powerful matrix function of MATLAB, there are not many gray GM $(1,1)$ model algorithms. (The gray model is generally expressed as $\operatorname{GM}(\mathrm{n}, \mathrm{x})$ model, which means that the $\mathrm{x}$ variables are modeled by n-order differential equations.) Based on the MATLAB grey GM $(1,1)$ model, this paper theoretically predicts the concentration of atmospheric pollutants in Xiong'an New District.

\section{Weighted Grey Relational Analysis Model of Urban Air Pollution Index}

Taking Xiong'an New Area as an example, the monitoring data of sulfur dioxide $\left(\mathrm{SO}_{2}\right)$, nitrogen dioxide $\left(\mathrm{NO}_{2}\right)$ and inhalable particulate matter $\left(\mathrm{PM}_{10}\right)$ were monitored at monitoring points in the three counties of Xiong'an from 2011 to 2016 [20] [21] [22]. According to the national environmental air quality standard, a weighted grey correlation analysis model is used to make a reasonable comprehensive evaluation of the air quality in Xiong'an New Area.

\subsection{Climatic Characteristics of Xiong'an New Area}

Xiong'an New Area includes Xiongxian, Rongcheng and Anxin counties in He- 
bei Province and some surrounding areas. Located in the hinterland of Beijing, Tianjin and Baoding, it has a temperate continental monsoon climate with distinct seasons, drought and windy spring, hot and rainy summer, cool autumn, cold and less-snow winter. The average annual temperature is $11.7^{\circ} \mathrm{C}$, the highest monthly (July) average temperature is $26^{\circ} \mathrm{C}$, and the lowest monthly (January) average temperature is $-4.9^{\circ} \mathrm{C}$ with the annual sunlight of 2685 hours and an average annual rainfall of $551.5 \mathrm{~mm}$, accounting for $80 \%$ from June to September, and a frost-free period of 191 days a year.

\subsection{Sources and Analysis Methods of Major Air Pollutants}

This paper analyzes the air pollution from the three factors of civil heating, dust raising and industrial pollution in Xiong' an New Area [23] [24].

Analysis of civil heating factors: the civil heating season leads to a decrease in air quality and a higher concentration of sulfur dioxide. Coal burning directly leads to an increase in pollutant concentration. Civil heating is an important factor affecting air quality. The level of economic development in Xiong'an County is relatively low, with coal-fired heating in rural areas and coal-fired heating in some county residents [25].

Analysis of the factors of floating dust: Xiong'an New Area is a city with little rain in the north, and the concentration of inhalable particulate matters in the air is higher than that in coastal cities, thus affecting the air quality in Xiong'an New Area.

Analysis of industrial pollution factors: The three counties of Xiong'an take plastic packaging, latex products, leather shoes and non-ferrous metal processing industries as the main pillar enterprises, and the development of the enterprises has also brought serious air pollution to the local area [26] [27].

Refer to Table 1 for the sources and analysis methods of the major atmospheric pollutants sulfur dioxide, nitrogen dioxide and inhalable particulate matters $\mathrm{PM}_{10}$.

\subsection{Monitoring Results of Concentration of Mainair Pollutants}

The continuous monitoring data of air pollution monitoring in Xiong'an New Area (from the real-time air quality publishing platform of Hebei Environmental Monitoring Center Stationadopts the Dongyu 1000 series air quality automatic

Table 1. Sources and Analysis methods of various pollutants.

\begin{tabular}{clc}
\hline Name of pollutant & \multicolumn{1}{c}{ Analytical method } & \multicolumn{1}{c}{ source } \\
\hline & $\begin{array}{l}\text { Sulfur dioxide }\left(\mathrm{SO}_{2}\right) \text { formaldehyde absorption para } \\
\text { rosaniline spectrophotometry; Mercury tetrachloride } \\
\text { parafuchsin spectrophotometry; UV fluorescence } \\
\text { method; }\end{array}$ & GB 8970-88 \\
Inhalable particulate matter dioxide $\left(\mathrm{SO}_{2}\right)$ & $\begin{array}{l}\text { Gravimetric analysis } \\
\text { Nitrogen dioxide }\left(\mathrm{NO}_{2}\right)\end{array}$ & $\begin{array}{l}\text { Saltzman analysis method Chemiluminescence } \\
\text { method }\end{array}$ \\
\hline
\end{tabular}


monitoring system. The main air pollutants are $\mathrm{O}_{3}, \mathrm{PM} 2.5, \mathrm{PM} 10, \mathrm{SO}_{2}, \mathrm{NO}_{2}$, $\mathrm{CO}$, etc., and the main pollutants which have serious impact on air quality are selected for analysis and research. The data in this paper are based on the annual average of air pollutants $\mathrm{SO}_{2}, \mathrm{NO}_{2}$ and $\mathrm{PM}_{10}$ (as shown in Table 2) from 2011 to 2016.

\subsection{Comprehensive Evaluation of Atmospheric Environmental Quality}

The evaluation criteria are listed in the National Air Quality Standard of the People's Republic of China (GB 3095-1996) and revised in 2000 (refer to Table 3).

Weighting is determined by considering population factors and weight distribution position. According to the contribution rate of evaluation factors of each evaluation unit, the weight coefficient of each evaluation factor of the unit to be evaluated can be determined.

The formula is as follows:

$$
\alpha_{i}=\frac{x_{i} / s_{i}}{\sum x_{i} / s_{i}}
$$

$\alpha_{i}$ - The weight coefficient of pollutant $I$;

$s_{i}$-Standard arithmetic mean of $i$ pollutant concentration;

$x_{i}$-The actual concentration value of pollutant $i$.

According to the formula, the weight of Xiong'an New Area in 2011-2016 is calculated (refer to Table 4).

Table 4 gives the values of the annual pollution weight factor $a_{i}$. The weight calculation results show that $\mathrm{SO}_{2}$ and $\mathrm{PM}_{10}$ are the main pollutants affecting the air quality in Xiong'an New Area. The main pollutants each year are $\mathrm{SO}_{2}(2011)$, $\mathrm{PM}_{10}$ (2012), $\mathrm{PM}_{10}$ (2013) and $\mathrm{SO}_{2}$ (2014-2016). In recent years, air pollution in Xiong'an New Area has gradually changed from $\mathrm{PM}_{10}$ to $\mathrm{SO}_{2}$, but there is still a long way to go to reduce the impact of $\mathrm{PM}_{10}$ on the environment.

\subsection{Evaluation Results of Weighted Grey Correlation}

$$
r=\frac{\sum_{i=1}^{n}\left(x_{i}-\bar{x}\right)\left(y_{i}-\bar{y}\right)}{\sqrt{\sum_{i=1}^{n}\left(x_{i}-\bar{x}\right)^{2} \cdot \sum_{i=1}^{n}\left(y_{i}-\bar{y}\right)^{2}}}
$$

$X_{\mathrm{i}}, y_{i}$ represent the actual value, the sequence of the fitted value,

$\bar{x}, \bar{y}$ represent the actual value and the average of the fitted values.

According to the above calculation method, the annual air quality calculation results are shown in Table 5.

The $\mathrm{r} 1, \mathrm{r} 2$ and $\mathrm{r} 3$ in Table 5 are the correlation coefficients of the theoretical data of $\mathrm{SO}_{2}, \mathrm{NO}_{2}$ and PM10 and the measured data.

Through the comprehensive analysis of Table 4 and Table 5, it is concluded that the air quality in Xiong'an New Area from 2011 to 2012 belongs to the III 
Table 2. Monitoring results of air pollutants in Xiong'an New Area.

\begin{tabular}{cccc}
\hline Year & $\mathrm{SO}_{2}\left(\mathrm{mg} / \mathrm{m}^{3}\right)$ & $\mathrm{NO}_{2}\left(\mathrm{mg} / \mathrm{m}^{3}\right)$ & $\mathrm{PM}_{10}\left(\mathrm{mg} / \mathrm{m}^{3}\right)$ \\
\hline 2011 & 0.134 & 0.033 & 0.109 \\
2012 & 0.137 & 0.039 & 0.107 \\
2013 & 0.084 & 0.036 & 0.098 \\
2014 & 0.079 & 0.025 & 0.109 \\
2015 & 0.077 & 0.022 & 0.097 \\
2016 & 0.063 & 0.032 & 0.087 \\
\hline
\end{tabular}

Table 3. Grading standards for atmospheric environmental quality.

\begin{tabular}{ccccc}
\hline \multirow{2}{*}{ Pollutant } & \multirow{2}{*}{ Sample time } & \multicolumn{3}{c}{ Limit concentration $\left(\mathrm{mg} / \mathrm{m}^{3}\right)$} \\
\cline { 3 - 5 } & & I level standard & II level standard & III level standard \\
\hline $\mathrm{SO}_{2}$ & Annual mean & 0.04 & 0.10 & 0.15 \\
$\mathrm{NO}_{2}$ & Annual mean & 0.04 & 0.08 & 0.08 \\
$\mathrm{PM}_{10}$ & Annual mean & 0.02 & 0.06 & 0.10 \\
\hline
\end{tabular}

Table 4. Weight calculation results.

\begin{tabular}{ccccc}
\hline \multirow{2}{*}{ Year } & \multicolumn{4}{c}{ Weight coefficient } \\
\cline { 2 - 5 } & $\mathrm{SO}_{2}$ & $\mathrm{NO}_{2}$ & $\mathrm{PM}_{10}$ & Primary pollutant \\
\hline 2011 & 0.489 & 0.133 & 0.378 & $\mathrm{SO}_{2}$ \\
2012 & 0.520 & 0.133 & 0.347 & $\mathrm{PM}_{10}$ \\
2013 & 0.400 & 0.191 & 0.409 & $\mathrm{PM}_{10}$ \\
2014 & 0.452 & 0.167 & 0.381 & $\mathrm{SO}_{2}$ \\
2015 & 0.449 & 0.131 & 0.420 & $\mathrm{SO}_{2}$ \\
2016 & 0.427 & 0.185 & 0.387 & $\mathrm{SO}_{2}$ \\
\hline
\end{tabular}

Table 5. Results of comprehensive evaluation in recent years.

\begin{tabular}{ccccc}
\hline \multirow{2}{*}{ Year } & \multicolumn{4}{c}{ Correlation degree } \\
\cline { 2 - 5 } & $\mathrm{r} 1$ & $\mathrm{r} 2$ & $\mathrm{r}$ & Quality level \\
\hline 2011 & 0.528 & 0.650 & 0.815 & III level \\
2012 & 0.433 & 0.502 & 0.347 & II level \\
2013 & 0.529 & 0.810 & 0.538 & II level \\
2014 & 0.137 & 0.623 & 0.090 & II level \\
2015 & 0.422 & 0.846 & 0.457 & II level \\
2016 & 0.467 & 0.816 & 0.439 & II level \\
\hline
\end{tabular}

level, that is, light pollution. From 2013 to 2016, the urban ambient air quality was 2 and the air was good. This indicates that the ambient air quality in the New Area is gradually improving. This good air quality benefits from the posi- 
tive measures taken by the State Environmental Protection Administration in recent years. The advantage of grey correlation analysis is that it can sort the quality of analysis environment. According to the order from high to low, the air quality is the best in 2014, and the situation is worse from 2011 to 2016.

\subsection{Evaluate According to the Season and Heating Cycle}

Each year is divided into heating period and non-heating period. The non-heating period is from March 15 to November 15 of each year, and the heating period is from November 15 to March 15. The evaluation results are shown in Table 6.

Table 6 shows that the air quality in Xiong'an New Area is good during non-heating period, with $\mathrm{PM}_{10}$ as the main pollutant. The air quality is relatively poor during the heating period, and the main pollutant is sulfur dioxide. It can be seen that Xiong'an New Area is a coal-polluted city and needs to further control coal pollution.

\section{Forecast of Air Pollution in Xiong'an New Area Based on Grey Model}

\subsection{Assumptions of Model}

Other pollutants in the atmosphere within a reasonable range are ignored; Ignoring the error of data in the process of detecting pollutants;

Assuming no major natural disasters such as earthquakes, sandstorms and floods, the city's natural environment will remain stable.

Assuming that no major industrial accident will occur in the past two years.

\subsection{Establishment of Grey Forecasting Model}

In order to ensure the consistency of the model parameter rate, the grey forecasting system theory was used to select data from August 2016 to March 2017, and the mass concentrations of $\mathrm{PM}_{10}, \mathrm{NO}_{2}$ and $\mathrm{SO}_{2}$ were selected within 6 months. According to the previous analysis results, three grey forecasting models of $\mathrm{PM}_{10}, \mathrm{NO}_{2}$ and $\mathrm{SO}_{2}$ in Xiong'an New Area are established respectively. The grey forecasting model is as follows:

$$
\begin{gathered}
\hat{\chi}_{(k+1)}^{1}=-5822.23 \exp (-0.0376 k)+6277.38 \\
\hat{\chi}_{(k+1)}^{1}=-2823.35 \exp (-0.0177 k)+4545.56 \\
\hat{\chi}_{(k+1)}^{1}=-822.67 \exp (-0.0736 k)+678.34
\end{gathered}
$$

(1) grey forecasting models of PM10.

(2) grey forecasting models of $\mathrm{NO}_{2}$.

(3) grey forecasting models of $\mathrm{SO}_{2}$.

\subsection{Test of Forecast Results}

According to the formula of grey forecasting model, the mass concentration of $\mathrm{SO}_{2}$ in the atmosphere in Xiong'an New Area from August 2016 to March 2017 
Table 6. Comprehensive evaluation results for the whole year.

\begin{tabular}{|c|c|c|c|c|c|c|}
\hline \multirow{2}{*}{ Year } & \multirow{2}{*}{ Term } & \multicolumn{3}{|c|}{ Pollutant concentration $\left(\mathrm{mg} / \mathrm{m}^{3}\right)$} & \multirow{2}{*}{ Quality level } & \multirow{2}{*}{$\begin{array}{c}\text { Primary } \\
\text { pollutant }\end{array}$} \\
\hline & & I level & II level & III level & & \\
\hline 2011 & Heating period & 0.373 & 0.515 & 0.584 & III level & $\mathrm{SO}_{2}$ \\
\hline \multirow[t]{2}{*}{2012} & Non-heating period & 0.642 & 0.801 & 0.701 & II level & $\mathrm{PM}_{10}$ \\
\hline & Heating period & 0.519 & 0.610 & 0.675 & III level & $\mathrm{SO}_{2}$ \\
\hline \multirow[t]{2}{*}{2013} & Non-heating period & 0.607 & 0.776 & 0.416 & II level & $\mathrm{PM}_{10}$ \\
\hline & Heating period & 0.466 & 0.557 & 0.766 & II level & $\mathrm{SO}_{2}$ \\
\hline \multirow[t]{2}{*}{2014} & Non-heating period & 0.679 & 0.645 & 0.392 & I level & $\mathrm{PM}_{10}$ \\
\hline & Heating period & 0.552 & 0.775 & 0.834 & III level & $\mathrm{SO}_{2}$ \\
\hline \multirow[t]{2}{*}{2015} & Non-heating period & 0.483 & 0.801 & 0.416 & II level & $\mathrm{PM}_{10}$ \\
\hline & Heating period & 0.452 & 0.543 & 0.792 & III level & $\mathrm{SO}_{2}$ \\
\hline 2016 & Non-heating period & 0.694 & 0.820 & 0.453 & II level & $\mathrm{PM}_{10}$ \\
\hline
\end{tabular}

is calculated. (See Figure 1) The forecasted value of the grey model is taken as the input value, and the actual value is the output value. Iterate input and output values. The maximum number of cycles is set to 5000 and the initial step size is $0.0001 \mathrm{~m}$.

The data processing shows that the experimental data and the theoretical data are basically fitted.

According to the formula of the grey forecasting model, $\mathrm{PM}_{10}, \mathrm{NO}_{2}$ and $\mathrm{SO}_{2}$ pollution in Xiong'an New Area (See Figure 2) will be obtained in the next 6 months, and the forecasting results of the grey forecasting model will be tested. The accuracy of the model was verified by residual error test and posterior error test. The results of the remaining tests are shown in Table 7.

\section{Conclusion}

Through the study of the air environmental quality in Xiong'an New Area from 2011 to 2016, it is found that the air environmental quality in the New District has greatly improved in the past six years, and the air environmental quality reached the III level in 2011 and 2012. Since 2013, the environmental quality has been maintained at II level, meeting the national requirements. However, the environmental quality is still in a state of constant repetition and it is necessary to continue efforts. Secondly, the grey correlation method is used to comprehensively analyze the air environmental quality in Xiong'an New Area. The results are in line with the actual situation and reach the expected evaluation results [28] [29] [30]. The grey correlation method is applicable to the comprehensive evaluation of Xiong'an New Area's air environment.

\section{Suggests}

"Green environmental protection, standards first" If Xiong'an New Area wants to realize the development vision of green ecology and livability, it must 


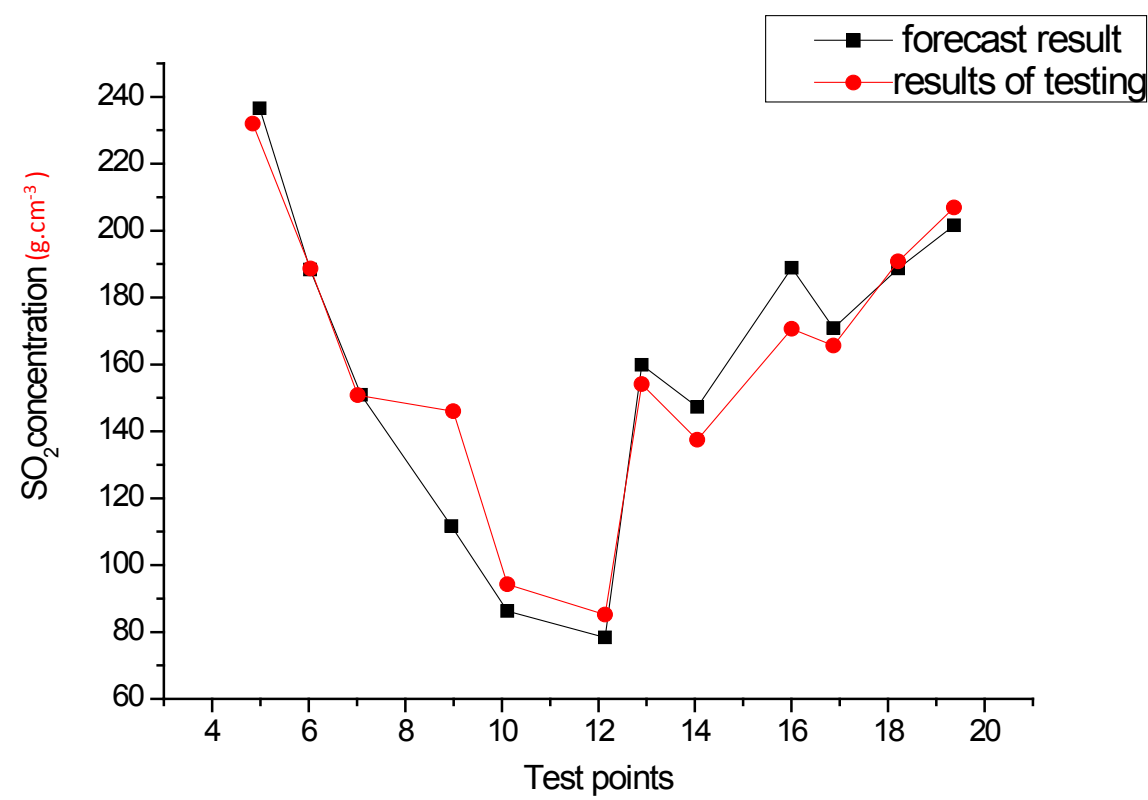

Figure 1. Forecasting of $\mathrm{SO}_{2}$ Concentration in Xiong'an New Area from August 2016 to March 2017.

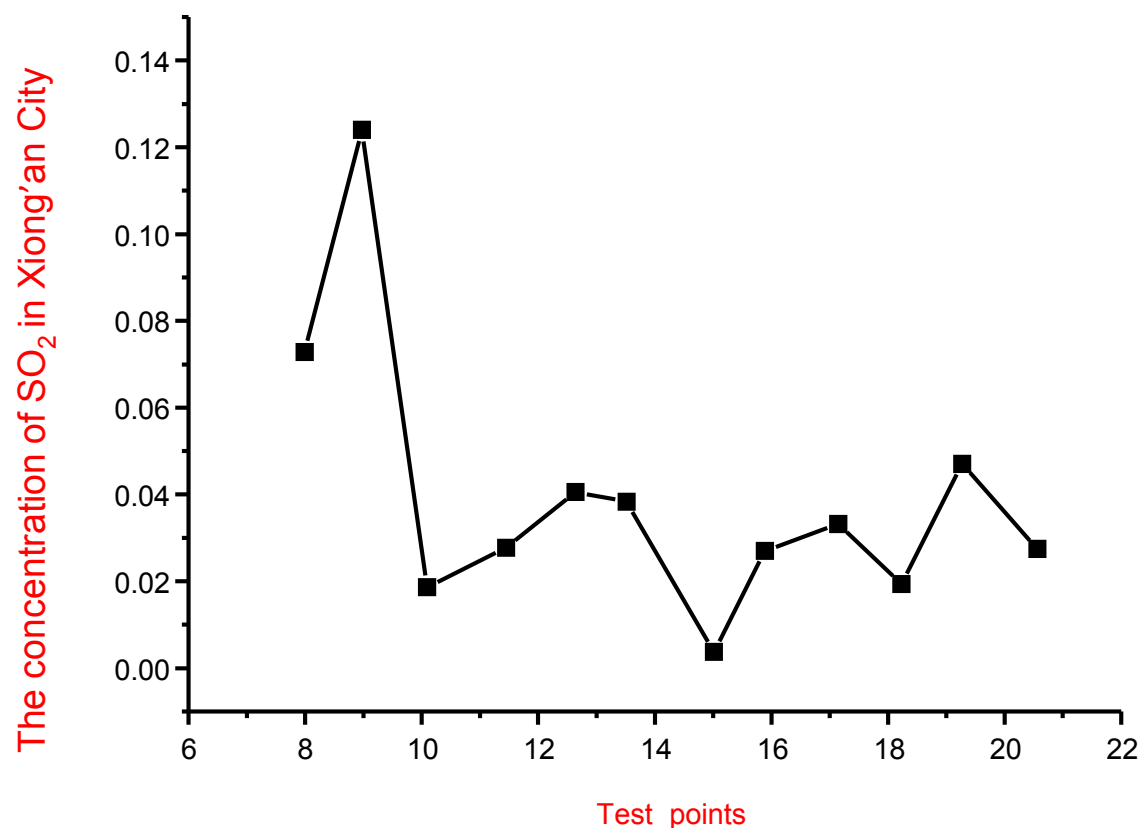

Figure 2. Forecasting of $\mathrm{SO}_{2}$ mass concentration in Xiong'an New Area.

Table 7. The results of residual error test and posterior error test.

\begin{tabular}{ccccc}
\hline \multirow{2}{*}{ Time } & \multicolumn{4}{c}{$\mathrm{SO}_{2}$} \\
\cline { 2 - 5 } & Monitoring value & Forecasted value & Residual error & Relative error (\%) \\
\hline 2016.08 & 86.53 & 61.0388 & -18.88676 & 18.43 \\
2016.10 & 100.61 & 121.1906 & 14.10033 & 17.24 \\
2016.12 & 189.53 & 139.7011 & 17.14607 & 7.79 \\
2017.02 & 237.36 & 185.6357 & 10.16509 & 21.79 \\
\hline
\end{tabular}


effectively crack the restrictive factors affecting environmental pollution, which requires that the industrial emission standards of enterprises settled in Xiong'an New Area should reach the international level, while the existing industrial standards in China are low and slow to update, and new standards are urgently needed. Based on the understanding of the surrounding environment of the New District, it is suggested that some teachers and scientific research departments in colleges and universities in the province may participate in the drafting of the standards.

\section{Conflicts of Interest}

The authors declare no conflicts of interest regarding the publication of this paper.

\section{References}

[1] Liang, W., Du, Y.X. and Hua, W.L. (2017) Application Research of Grey GM(1,1) Model Based on Matlab. Journal of Suzhou University, 32, 92-93.

[2] Ambient Air Quality Standards (2012).

[3] Cheng, N.L., Zhang, D.W., Li, Y.T., Chen, T., Li, J.X., Dong, X., et al. (2015) Analysis about Spatial and Temporal Distribution of so2 and an Ambient so2 Pollution Process in Beijing during 2000-2014. Huan Jing Ke Xue, 36, 3961-3971.

[4] Du, W., Zhao, J., Wang, Y.Y., et al. (2017) Simultaneous Measurements of Particle Number Size Distributions at Ground Level and $260 \mathrm{~m}$ on a Meteorological Tower in Urban Beijing, China. Atmospheric Chemistry \& Physics, 17, 6797-6811. https://doi.org/10.5194/acp-17-6797-2017

[5] Dong, J.Y., Liu, X.R., Zhang, B.Z., et al. (2015) Correlation Analysis between Atmospheric Relative Humidity and PM10 Concentration and Atmospheric Visibility in Lanzhou City. Chinese Journal of Ecology and Environment, 24, 1995-2001.

[6] He, K.B., Jia, Y.X., Ma, Y.L., et al. (2009) The Regional Nature of Atmospheric Particulate Matter Pollution in Beijing. Journal of Environmental Science, 29, 482-487.

[7] Li, Y.T., Cheng, N.L., Zhang, D.W., et al. (2015) Study on PM2.5 Background Concentration in Different Orientations in Beijing in 2013. Environmental Science, 36, 4331-4339.

[8] Liu, J., Zhang, X.-L., Xu, X.-F., et al. (2008) Suburban Contrast Analysis of the Variation Characteristics of $\mathrm{SO}_{2}, \mathrm{NOx}, \mathrm{O}_{3}$ and PM2.5 in Beijing Area. Environmental Science, 29, 1059-1065.

[9] Wang, L.-L., Wang, Y.-S., Ji, D.-S., et al. (2011) Characteristics of Air Pollution in Autumn and Winter in Tianjin Binhai New Area. China Environmental Science, 31, 1077-1086.

[10] Wang, W., Tang, S., Liu, H.J., et al. (2000) Study on Pollution Status and Pollution Characteristics of PM2.5 in China. Journal of Environmental Science, 13, 1-5.

[11] Liu, H.M., Fang, C.L., Huang, J.J., et al. (2018) Analysis of Temporal and Spatial Characteristics and Influencing Factors of Atmospheric Pollution in Beijing-Tianjin-Hebei Urban Agglomeration. Acta Geographica Sinica, 1, 177-191.

[12] Gu, W., Sun, Z., Wei, X. and Dai, H. (2014) A New Method of Accelerated Life Testing Based on the Grey System Theory for a Model-Based Lithium-Ion Battery Life Evaluation System. Journal of Power Sources, 267, 366-379.

https://doi.org/10.1016/j.jpowsour.2014.05.103 
[13] Gupta, G.P., Kumar, B. and Kulshrestha, U.C. (2016) Impact and Pollution Indices of Urban Dust on Selected Plant Species for Green Belt Development: Mitigation of the Air Pollution in Ncr Delhi, india. Arabian Journal of Geosciences, 9, 136. https://doi.org/10.1007/s12517-015-2226-4

[14] Li, G.D., Masuda, S. and Nagai, M. (2015) Predictor Design Using an Improved Grey Model in Control Systems. International Journal of Computer Integrated Manufacturing, 28, 297-306. https://doi.org/10.1080/0951192X.2014.880801

[15] Kadiyala, A. and Kumar (2012) A Vector Time Series Models for Prediction of Air Quality Inside a Public Transportation Bus Using Available Software. Environmental Progress \& Sustainable Energy, 31, 494-499. https://doi.org/10.1002/ep.11708

[16] Moazami, S., Noori, R., Amiri, B.J., Yeganeh, B., Partani, S. and Safavi, S. (2016) Reliable Prediction of Carbon Monoxide Using Developed Support Vector Machine. Atmospheric Pollution Research, 7, 412-418. https://doi.org/10.1016/j.apr.2015.10.022

[17] Peng, Z.R., Wang, D.S., Wang, Z.Y., et al. (2015) A Study of Vertical Distribution Patterns of PM2.5, Concentrations Based on Ambient Monitoring with Unmanned Aerial Vehicles: A Case in Hangzhou, China. Atmospheric Environment, 123, 357-369.

[18] Ogunkunle, C.O., Suleiman, L.B., Oyedeji, S., Awotoye, O.O. and Fatoba, P.O. (2015) Assessing the Air Pollution Tolerance Index and Anticipated Performance Index of Some Tree Species for Biomonitoring Environmental Health. Agroforestry Systems, 89, 447-454. https://doi.org/10.1007/s10457-014-9781-7

[19] Shi, G.M., Wang, J.N., Fu, F. and Xue, W.B. (2016) A Study on Transboundary Air Pollution Based on a Game Theory Model: Cases of So 2, Emission Reductions in the Cities of Changsha, Zhuzhou and Xiangtan in China. Atmospheric Pollution Research, 8, 244-252. https://doi.org/10.1016/j.apr.2016.09.003

[20] Ministry of Environmental Protection, State Administration of Quality Supervision, Inspection and Quarantine (2012) GB3095-2012, Ambient Air Quality Standards. China Environmental Science Press, Beijing.

[21] Ministry of Environmental Protection (2012) HJ633-2012, Environmental Air Quality Index (AQI) Technical Regulations (Trial). China Environmental Science Press, Beijing.

[22] Ministry of Environmental Protection (2013) HJ633-2013, Technical Specifications for Environmental Air Quality Assessment (Trial). China Environmental Science Press, Beijing.

[23] Meng, R. (2018) Analysis of Regional Characteristics of Air Pollution in Hebei Province. Environmentally Friendly Building Materials, No. 4, 47.

[24] Pei, B., Xue, Y., Zhong, L., et al. (2017) Emission Characteristics and Control Countermeasures of Coal-Fired Air Pollution in Beijing-Tianjin-Hebei Residents. Environmental Protection, No. 21, 27-31.

[25] Jia, W., Wang, W., Chen, Y., et al. (2010) Effects of Dust Aerosols on Cloud Radiation Forcing in North China. China Environmental Science, 30, 1009-1014.

[26] Peng, X. (2018) Study on the Variation Law and Influencing Factors of Air Pollution in Beijing-Tianjin-Hebei Region. China University of Geosciences, Beijing.

[27] Wu, J., Wang, W., Li, K., et al. (2017) Comparison of Spatial Differentiation Simulation Models of PM2.5 Concentration: Taking the Beijing-Tianjin-Hebei Region as an Example. Environmental Science, No. 6, 2191-2201

[28] Ren, Y., Li, X., Jin, M., et al. (2007) Cross-Sectional Study of Atmospheric Particu- 
late Matter Pollution and Death from Cardiovascular Disease. China Environmental Science, 27, 657-660.

[29] Li, Z. (2018) Environmental Monitoring Analysis and Countermeasures for Air Pollution Problems. Environment and Development, No. 4, 184-186.

[30] Ma, L. and Qi, S. (2018) Environmental Monitoring and Governance Analysis of Urban Air Pollution. Chemical Design Communications, No. 3, 171-172. 